\title{
Effect of carbon fibers on thermal properties and mechanical strength of ceramizable composites based on silicone rubber
}

\author{
M. Imiela ${ }^{1}$ R. Anyszka ${ }^{1} \cdot$ D. M. Bieliński ${ }^{1}$. \\ Z. Pędzich ${ }^{2}$ M. Zarzecka-Napierała ${ }^{2}$ M. Szumera ${ }^{2}$
}

Received: 21 May 2015/Accepted: 19 October 2015/Published online: 16 November 2015

(C) The Author(s) 2015. This article is published with open access at Springerlink.com

\begin{abstract}
Ceramizable (ceramifiable) silicone composites are one of the most important elastic technical materials produced industrially. These composites are commonly used to increase flame retardancy of electrical cables and to ensure integrity of electricity network during fire by their ability to create a continuous ceramic structure. In this paper, ceramizable silicone composites filled with different contents of carbon fibers were tested. The research was focused on the characterization of ceramic structure created during heat treatment of the composites and thermal properties of the composites. For this purpose, morphology (SEM) and compression strength of the ceramic structures were studied. To describe process of ceramic structures creation, TG/DSC analysis was done. These tests have demonstrated that, the increase in carbon fibers amount
\end{abstract}

M. Imiela

800655@edu.p.lodz.pl

R. Anyszka

rafal.anyszka@p.lodz.pl

D. M. Bieliński

dariusz.bielinski@p.lodz.pl

Z. Pędzich

pedzich@agh.edu.pl

M. Zarzecka-Napierała

zarzecka@agh.edu.pl

M. Szumera

mszumera@agh.edu.pl

1 Faculty of Chemistry, Institute of Polymer and Dye Technology, Lodz University of Technology, Stefanowskiego 12/16, 90-924 Lodz, Poland

2 Department of Ceramics and Refractory Materials, Faculty of Material Science and Ceramics, AGH - University of Science and Technology, Al. Mickiewicza 30, 30-045 Kraków, Poland improves the mechanical properties of ceramic structure regardless of heat treatment conditions.

Keywords Polymer composites - Ceramization · Ceramification - Silicone rubber $\cdot$ Carbon fibers

\section{Introduction}

Ceramization process has been already quite widely described in the literature. This process is characterized by creation of stiff, durable and porous ceramic structure from highly filled polymer composite during heat treatment. The created structure can block propagation of flames and decrease rate of flammable, caloric fuel production, created during thermooxidative destruction of polymer matrix, by preventing burning material from deeper penetration of oxygen. Because of high flammability of unfilled elastomer materials, composites destined for wire covers should contain effective flame retardants $[1,2]$. One of the most efficient ways to assure required level of fire safety of cables is incorporation of large amount of filler mix promoting ceramization, which provide outstanding mechanical properties of mineral residue created during firing [3-9].

Creation of the ceramic structure can take place in several ways: (1) formation of a continuous and porous structure involving amorphous fluxing agent, which softens in elevated temperature and sticks thermally stable mineral particles together [10], (2) creation of silica connections between particles of mineral filler during thermooxidative degradation of silicone matrix $[11,12]$ and (3) creation of silicon oxycarbide (SiOC) ceramic phase due to deposition, crosslinking and volatilization of siloxane macromolecules on the surface of reinforcing silica particles dispersed in silicone matrix in the presence of platinum complex [13]. 
In our previous research, we used $\mathrm{B}_{2} \mathrm{O}_{3}$ as a fluxing agent, ceramic, crystalline powder, which is characterized by melting point temperature $\left(T_{\mathrm{m}}\right)$ of $450{ }^{\circ} \mathrm{C}$ [14]. Low $T_{\mathrm{m}}$ value of $\mathrm{B}_{2} \mathrm{O}_{3}$ makes it effective fluxing agent, but its acidic and hydrophilic character can cause problems during compounding and processing of composites. Marosi et al. showed that also boro-siloxanes can be used as efficient fluxing agent even for organic polymers [15]. However, in present work, we decided to use glassy oxide frit containing large amount of $\mathrm{Na}_{2} \mathrm{O}$, which decreases its softening point temperature significantly. The use of this kind of frit makes compounding and processing of the ceramizable silicone composite much securer [16]. Mechanisms 2 and 3 are not as relevant as mechanism 1 from the point of view of ceramic structure strength, but their impact favors silicone rubber in role of continuous phase for ceramizable composites.

Selection of the appropriate fillers for ceramizable composite is extremely important, because chosen fillers, after polymer matrix degradation, serve as backbone of the ceramic structure. Mineral fillers can also increase flame retardancy of the composites by their endothermic decomposition, release of chemically bound water and formation of a layer of oxide that protects bulk of the composite against further thermal degradation [17]. Also
Table 1 Composition of the silicone composites studied

\begin{tabular}{ll}
\hline Components & Content/phr \\
\hline Silicone pre-mix, Polsil MV-007 (30 phr of silica) & 100 \\
Mica & 30 \\
Fluxing agent & 25 \\
Carbon fibers & $0,1,3,5,7$ \\
2,4-dichlorobenzoyl peroxide & 2
\end{tabular}

size of filler particles influences mechanical strength of ceramic phase. Reduction in the average particle size allows for better dispersion of filler and increases the surface area of filler where silica or SiOC ceramic can be deposited. The size of filler particles also most often influences flame retardancy of polymer composites, smaller particles act in solid phase performing creation of more barrier char, increasing flame resistance [18]. On the other hand, with particle size decreasing, their ability to aggregation and agglomeration increases what can cause completely opposite effect, if the affinity between polymer matrix and the filler surface is poor [19].

Carbon fibers are becoming more and more popular. For example, recently Airbus, one of the biggest aircraft manufacturers, focused on application of carbon-fiber-
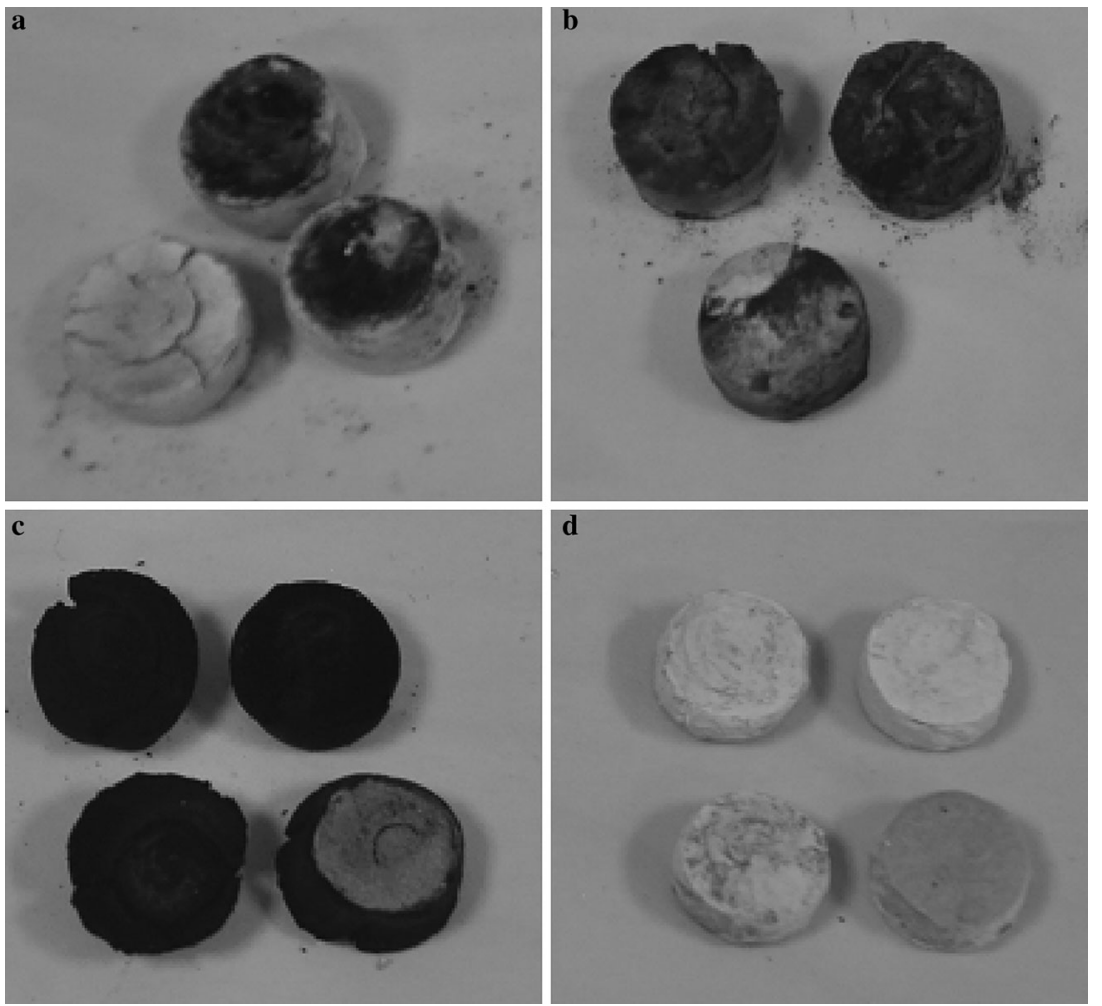

Fig. 1 Effect of heat treatment conditions on morphology and stability of dimensions of the silicone composite filled with 5 phr of carbon fibers. (a $600{ }^{\circ} \mathrm{C} / \mathrm{rapid}$, b $800{ }^{\circ} \mathrm{C} / \mathrm{rapid}$, c $1000{ }^{\circ} \mathrm{C} / \mathrm{rapid}$, d $950{ }^{\circ} \mathrm{C} /$ slow) 
Table 2 Compression strength of the ceramized silicone composites studied

\begin{tabular}{lcrr}
\hline $\begin{array}{l}\text { Carbon fibers } \\
\text { content/phr }\end{array}$ & \multicolumn{3}{l}{ The average maximum force/N } \\
\cline { 2 - 4 } & \multicolumn{1}{c}{$800{ }^{\circ} \mathrm{C}$} & \multicolumn{1}{c}{$1000{ }^{\circ} \mathrm{C}$} & \multicolumn{1}{c}{$\mathrm{s} 950{ }^{\circ} \mathrm{C}$} \\
\hline 0 & $28.8 \pm 7.6$ & $46.7 \pm 28.8$ & $43.7 \pm 18.6$ \\
1 & $90.1 \pm 19.0$ & $50.1 \pm 16.0$ & $44.1 \pm 28.7$ \\
3 & $92.4 \pm 48.4$ & $126.5 \pm 55.2$ & $96.3 \pm 49.0$ \\
5 & $144.3 \pm 32.8$ & $187.9 \pm 90.3$ & $147.2 \pm 62.6$ \\
7 & $181.3 \pm 23.6$ & $175.3 \pm 96.7$ & $146.4 \pm 61.4$ \\
\hline
\end{tabular}

s950 ${ }^{\circ} \mathrm{C}$, slow heating; $800{ }^{\circ} \mathrm{C}, 1000{ }^{\circ} \mathrm{C}$, rapid heating

reinforced thermoplasts in aircraft technology because of their excellent mechanical properties and ability to full recycling [20]. Carbon fibers exhibit tensile strength of 2800-5000 MPa [21]. Among others, carbon fibers are applied to production of high-quality laminates based on epoxy resin, which are widely used in building industry [22]. In medical field, carbon fibers are used as polymer reinforcement for composites utilized for orthopedic rails manufacturing [23].

In this paper, the influence of carbon fibers addition on properties of ceramizable silicone-based composites is presented. Thermal stability and ability to ceramic structure creation of composites filled with different amount of carbon fibers was examined, taking into account their micromorphology and mechanical strength.

\section{Experimental}

\section{Materials}

As an elastomer base, high-temperature vulcanizable silicone rubber (HTV) containing $0.07 \% \mathrm{~mol} / \mathrm{mol}$ of vinyl groups, produced by "Polish Silicones" Ltd., and reinforced by $30 \mathrm{phr}$ (parts per hundred weight parts of rubber) of "Aerosil 200" (Evonik Industries) fumed silica was used. Mica phlogopite "PW30" [containing 40-42\% $\mathrm{SiO}_{2}$, $20-26 \% \mathrm{MgO}, 10-11 \% \mathrm{~K}_{2} \mathrm{O}, 9-11 \% \mathrm{Al}_{2} \mathrm{O}_{3}, 3-11 \%$ $\mathrm{Fe}_{2} \mathrm{O}_{3}$ and 1-3\% other compounds (Minelco Minerals)] was used as a filler to enhance properties of ceramic structure. Glass frit FR-2050 (Reimbold und Strick; having a softening point temperature at $515{ }^{\circ} \mathrm{C}$ ) was used as a fluxing agent in composite. This glass frit is a mix of oxides consisting of $27.1 \% \mathrm{Na}_{2} \mathrm{O}, 6.8 \% \mathrm{CaO}, 1.7 \%$ $\mathrm{Al}_{2} \mathrm{O}_{3}, 64.4 \% \mathrm{SiO}_{2}$. Carbon fibers (T-101T, Kreca), with elasticity modulus of $30 \mathrm{GPa}$, were used to improve mechanical properties of composites. 2,4-dichlorobenzoyl peroxide ( $50 \%$ paste) was used as a curing agent.

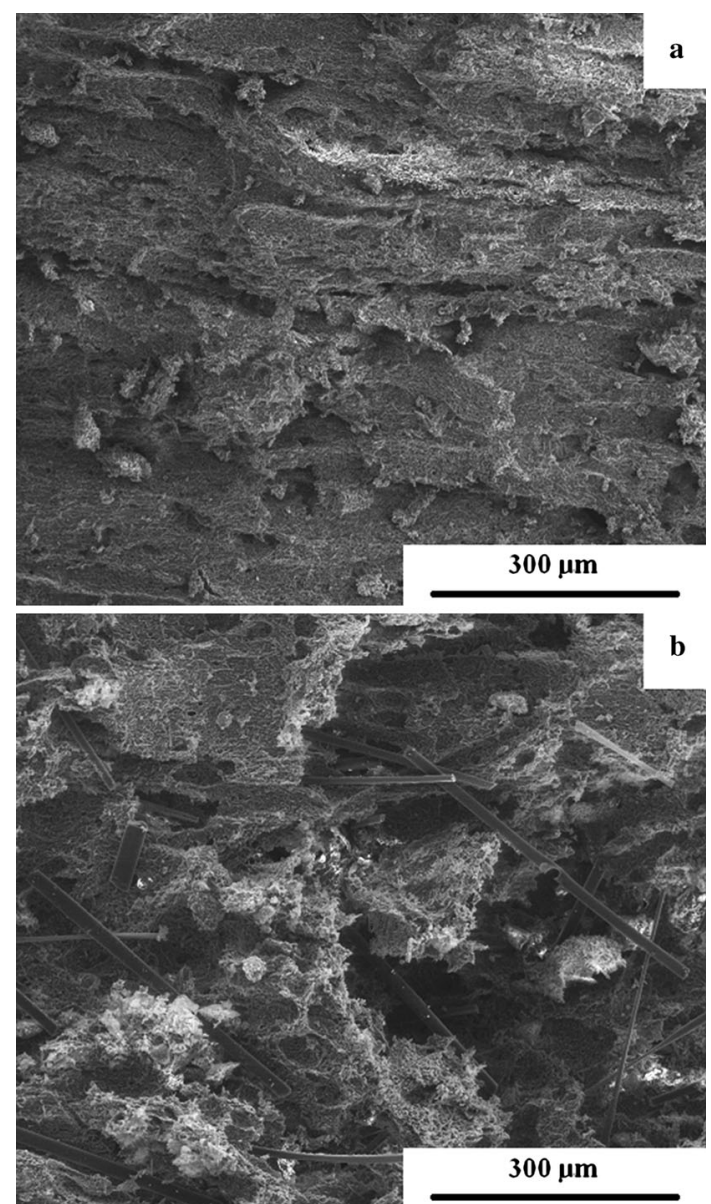

Fig. 2 Cross-section micromorphology (SEM) of silicone composite filled with $7 \mathrm{phr}$ of carbon fibers, treated thermally in different conditions $\left(\right.$ a $950{ }^{\circ} \mathrm{C} /$ slow, b $\left.1000{ }^{\circ} \mathrm{C} / \mathrm{rapid}\right)$

\section{Preparation of the samples}

Composite mixes (Table 1) were prepared by Brabender Plasticorder laboratory mixer (Germany), rotors operating with speed of $20 \mathrm{rpm}$ (components incorporation phase, $10 \mathrm{~min}$ ) and with $40 \mathrm{rpm}$ (components homogenization phase, $20 \mathrm{~min}$ ). Samples were vulcanized in electrically heated laboratory press, in steel molds, at $130^{\circ} \mathrm{C}$, during $10 \mathrm{~min}$.

\section{Techniques}

Prepared mixes were vulcanized in form of cylindrical shape (height $14 \mathrm{~mm}$, radius $16 \mathrm{~mm}$ ). The samples were heated in two different conditions. In the first one, composites were heated from room temperature up to $950{ }^{\circ} \mathrm{C}$ (heating rate $\sim 8{ }^{\circ} \mathrm{C} \mathrm{min}^{-1}$ ); in the second method, samples were treated by placing in previously heated furnace up to 600,800 or $1000{ }^{\circ} \mathrm{C}$ and left for $20 \mathrm{~min}$. After that, 


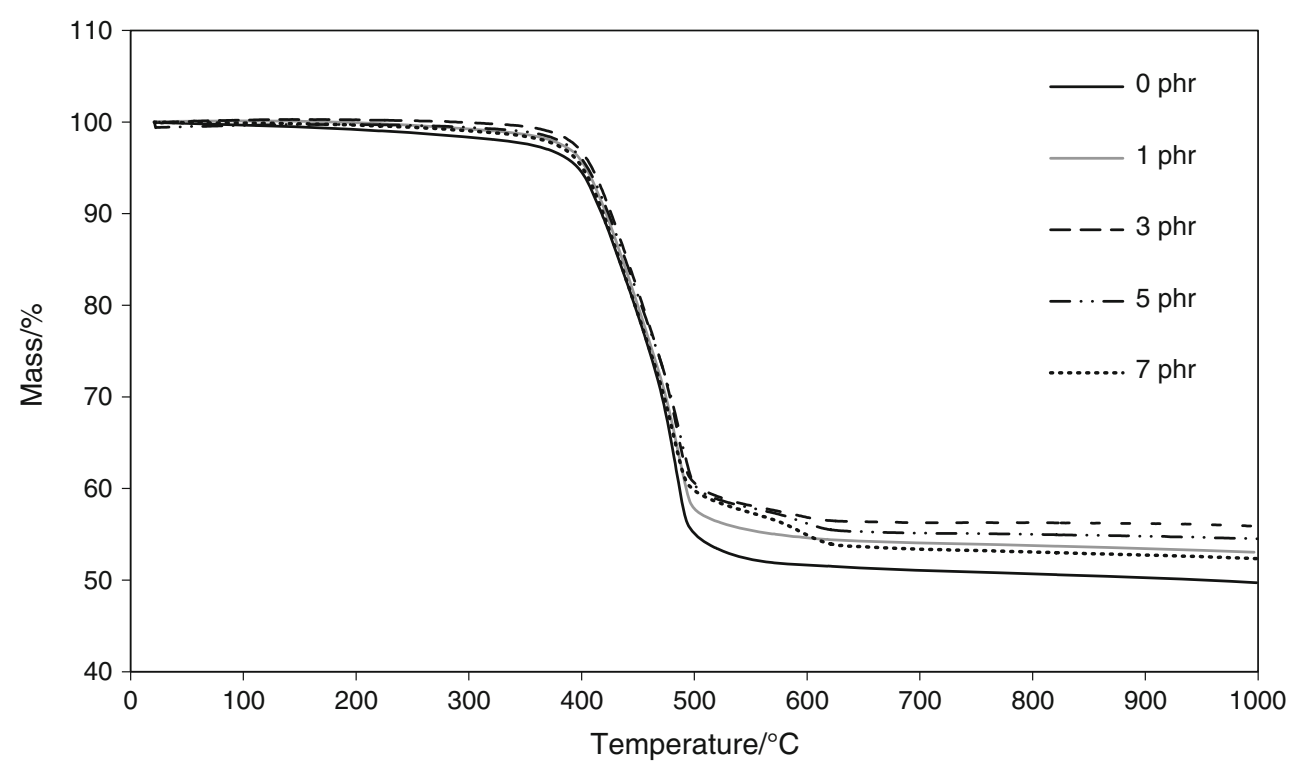

Fig. 3 TG analysis of the samples studied

Fig. 4 DTG analysis of the samples studied

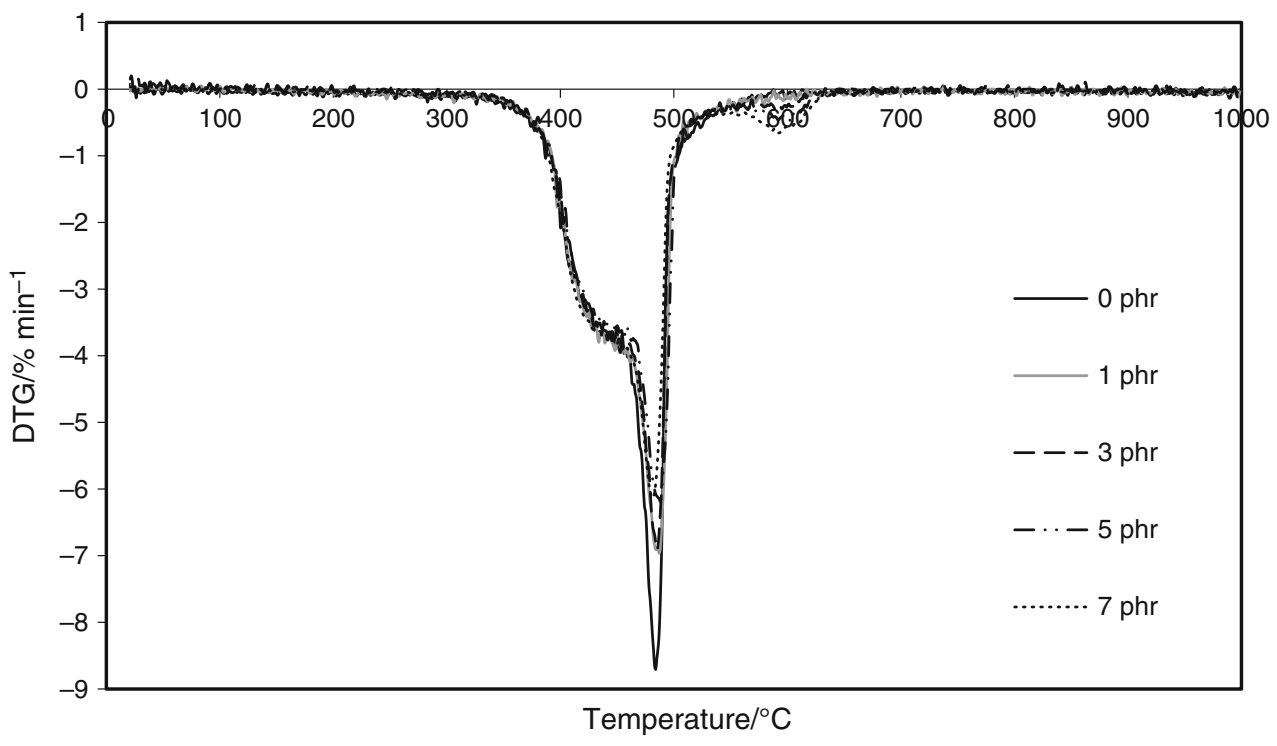

Table 3 Parameters of thermooxidative decomposition of the samples

\begin{tabular}{lllll}
\hline $\begin{array}{l}\text { Carbon fibers } \\
\text { content/phr }\end{array}$ & $\begin{array}{l}\text { Maximal degradation } \\
\text { rate/\% } \mathrm{min}^{-1}\end{array}$ & $\begin{array}{l}\text { First exothermal } \\
\text { maximum/mW mg }\end{array}$ & $\begin{array}{l}\text { Second exothermal } \\
\text { maximum/mW mg }\end{array}$ & $\begin{array}{l}\text { Amount of } \\
\text { ceramic char/\% }\end{array}$ \\
\hline 0 & -8.70 & 1.13 & None & 49.7 \\
1 & -6.96 & 1.86 & 0.61 & 53.0 \\
3 & -6.91 & 1.90 & 0.92 & 55.9 \\
5 & -6.18 & 1.83 & 1.03 & 54.5 \\
7 & -6.13 & 1.97 & 1.24 & 52.4 \\
\hline
\end{tabular}


Fig. 5 DSC analysis of the samples studied

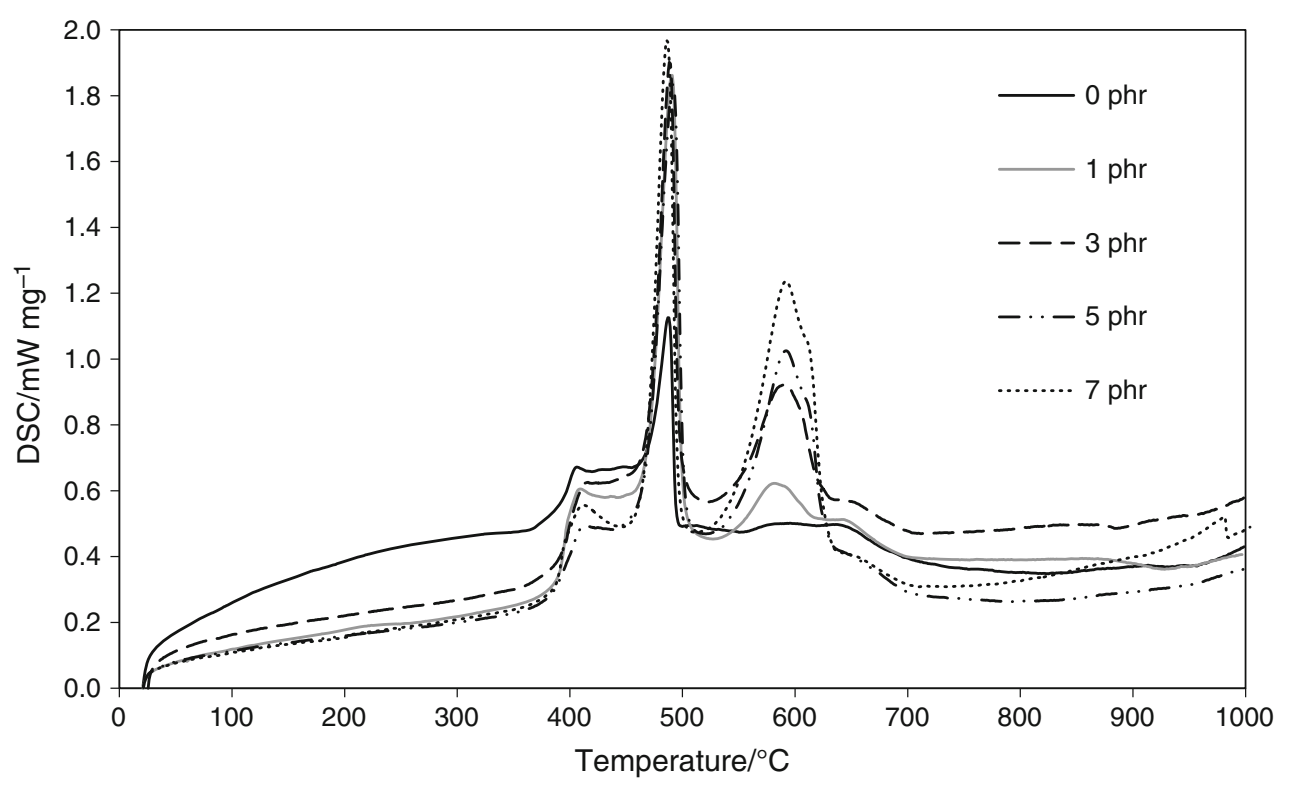

Room temperature
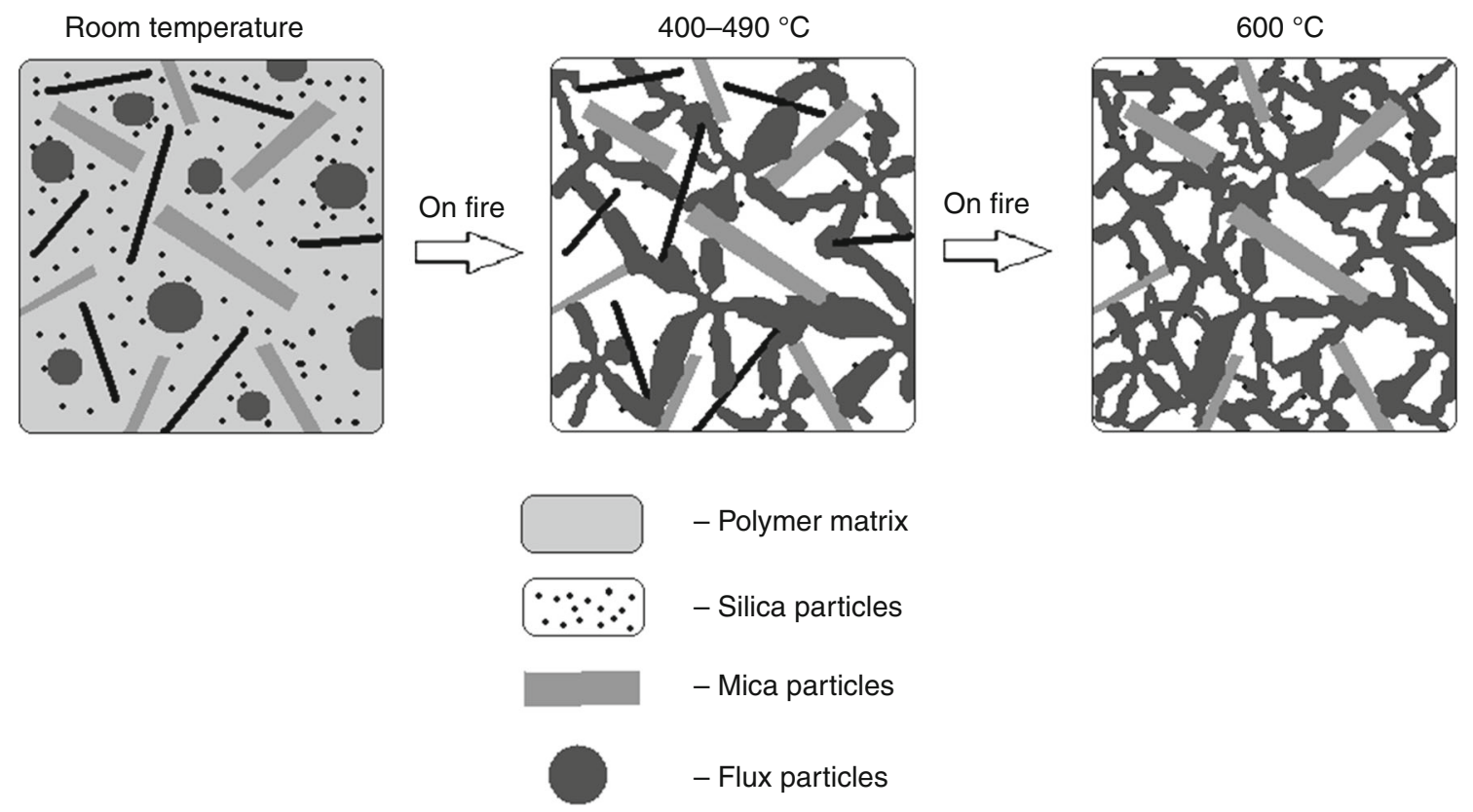

Fig. 6 Scheme illustrating ceramization process of silicone composites filled with carbon fibers

samples were subjected to compression test by means of Zwick Roell Z2.5 apparatus (Germany). Average values of maximal force required to crush the samples were calculated from three samples measurement.

Micromorphology of ceramized samples was examined by means of FEI Nova Nano SEM 200 scanning electron microscope (UK).

Thermal stability of the composites was determined by means of Netzsch STA 449F3 Jupiter (Germany) TG-DSC device. All samples were heated from room temperature to $1000{ }^{\circ} \mathrm{C}$ with the heating rate of $10{ }^{\circ} \mathrm{C} \min ^{-1}$ under air atmosphere (mass of the samples: $0 \mathrm{phr}-18.0 \mathrm{mg}$; $1 \mathrm{phr}-$ $21.3 \mathrm{mg} ; 3 \mathrm{phr}-16.7 \mathrm{mg} ; 5 \mathrm{phr}-19.8 \mathrm{mg} ; 7 \mathrm{phr}-20.4$ $\mathrm{mg})$.

\section{Results and discussion}

\section{Ceramization of the composites}

The photographs presented in the figure one illustrate the composites after different kinds of ceramization. Samples 
heated fast, by placing in furnace previously heated up to 600 , 800 or $1000{ }^{\circ} \mathrm{C}$, exhibit irregular cracks, shapechanges and appearance of black powder, which is most probably carbon black-char created as a result of rapid crosslinking and carbonization of silicone rubber exposed to very high temperature. The amount of carbon char visibly increases with the rise in furnace temperature. Samples heated slowly up to $950{ }^{\circ} \mathrm{C}$ show higher dimensional stability and integrity (lack of cracks) than other samples. What is more, less severe conditions of heat treatment resulted in lack of organic carbon char (Fig. 1).

\section{Properties of ceramic phase after heat treatment}

Compression strength of the composites depends on the heat treatment type and temperature, as well as content of carbon fibers. The results of compression strength test are shown in Table 2.

Not all composites were able to create a strong ceramic structure at $600{ }^{\circ} \mathrm{C}$ because of too low temperature of treatment. In higher temperatures, robust ceramic structures were created. Compression strength of the studied samples increases significantly with an increase in carbon fibers. The highest increase in compression strength was obtained after rapid treatment in $800{ }^{\circ} \mathrm{C}$, where sample filled with 7 phr of carbon fibers exhibited over 6 times higher strength than unfilled reference sample. This considerable increase in compression strength value is a result of reinforcing properties of unburned carbon fibers present in ceramic structure even after $1000^{\circ} \mathrm{C}, 20$-min heat treatment (Fig. 2b). The significant percolation threshold of mechanical properties increase can be observed for $800{ }^{\circ} \mathrm{C}$, 20-min treatment after addition of 1 phr of fibers, for $1000{ }^{\circ} \mathrm{C}, 20$-min treatment after addition of $3 \mathrm{phr}$ of fibers and for $950{ }^{\circ} \mathrm{C}$ slow treatment after incorporation $5 \mathrm{phr}$ of fibers. Addition of $7 \mathrm{phr}$ of carbon fibers does not enhance compression strength of the composite in comparison with the sample filled with $5 \mathrm{phr}$ of the fibers. Samples, which were subjected to a slow heat treatment, show enhanced compression strength, even without the presence of carbon fibers in the composites structure (Fig. 2a).

\section{Thermal properties of composites}

The above result can be explained by DSC analysis, which shows additional, exothermal effect for samples containing carbon fibers, around $600{ }^{\circ} \mathrm{C}$, being result of carbon fibers firing (Fig. 5). Additional amount of heat, provided over temperature of fluxing agent softening point, was probably consummated on decrease in fluxing agent viscosity, which resulted in more efficient bonding of mica flakes and silica particles created by silicone matrix firing (Fig. 6).
TG/DTG analysis shows that addition of carbon fibers enhances thermal stability of ceramizable composites with an optimal amount of 3 phr (Figs. 3, 4). Amount of ceramic, protective char created after thermooxidative degradation of this sample equals $55.9 \%$ (Table 3). The beginning of the siloxane matrix degradation starts at roughly $400{ }^{\circ} \mathrm{C}$. At ca. $490{ }^{\circ} \mathrm{C}$, the samples undergo maximal degradation rate, which decreases with an increase in carbon fibers content. However, addition of carbon fibers also increases the amount of heat generated during thermooxidative degradation of the samples (Fig. 5). Addition of even 1 phr of the fibers resulted in a significant increase in first exothermal peak value, though this value is independent of amount of carbon fibers in the composites. The increase in first exothermal peak is probably an effect of carbon fibers surface oxidation. Second exothermal peak, present at ca. $600{ }^{\circ} \mathrm{C}$, is an effect of carbon fibers firing, and its value increases with an increase in the fibers content. Heat released from carbon fibers burning additionally enhances mechanical properties of the ceramic residue structures (Fig. 6).

\section{Conclusions}

The results of this study show that addition of even relatively low amount of carbon fibers can successfully enhance mechanical properties of ceramic char structure, what is very important from the point of view of ceramizable cable covers utilization. Ceramic phases, which were formed from silicone rubber composites, exhibit even several times higher compression strength after addition of carbon fibers. Combustible fibers emit additional heat during slow thermal treatment, which allows the fluxing agent to create stronger bonds between the mica and silica particles. After rapid heat treatment, most of the fibers remained unburned and they reinforced the ceramic structures significantly. Moreover, thermal stability of the composites filled with the fibers was enhanced, with an optimum for the sample containing $3 \mathrm{phr}$ of carbon fibers. On the other hand, addition of flammable carbon fibers increases summary amount of heat generated during thermooxidative degradation what can accelerate spreading of fire. However, in situation when maintaining of integrity of an electric network plays a major role, the addition of carbon fibers can increase safety of the network significantly.

\section{Additional information}

Ceramizable silicone composites presented in this publication are subject of Polish Patent Application No. P.411011. 
Acknowledgements Sincere thanks to Martyna Kościukiewicz for providing language help: https://pl.linkedin.com/pub/martyna-kościu kiewicz/108/456/76b/pl. 'Young Scientists' Fund at the Faculty of Chemistry, Lodz University of Technology, Grant W-3/FMN/30G/ 2015.

Open Access This article is distributed under the terms of the Creative Commons Attribution 4.0 International License (http://crea tivecommons.org/licenses/by/4.0/), which permits unrestricted use, distribution, and reproduction in any medium, provided you give appropriate credit to the original author(s) and the source, provide a link to the Creative Commons license, and indicate if changes were made.

\section{References}

1. Rybiński P, Janowska G, Kucharska-Jastrząbek A, Pająk A, Wójcik I, Wesołek D, Bujnowicz K. Flammability of vulcanizates of diene rubbers. J Therm Anal Calorim. 2012;107:1219-24.

2. Rybiński P, Janowska G. Effect of the spatial network structure and cross-link density of diene rubbers on their thermal stability and fire hazard. J Therm Anal Calorim. 2014;117(1):377-86.

3. Mansouri J, Wood CA, Roberts K, Cheng YB, Burford RP. Investigation of the ceramifying process of modified siliconesilicate compositions. J Mater Sci. 2007;42:6046-55.

4. Dul J, Parys G, Pędzich Z, Bieliński DM, Anyszka R. Mechanical properties of silicone-based composites destined for wire covers. Int J Adv Mater Manuf Charact. 2012;1:23-8.

5. Bieliński DM, Anyszka R, Pędzich Z, Dul J. Ceramizable silicone rubber-based composites. Int $\mathrm{J}$ Adv Mater Manuf Charact. 2012;1:17-22.

6. Pędzich Z, Bieliński DM. Microstructure of silicone composites after ceramization. Composites. 2010;10:249-54.

7. Pędzich Z, Bukanska A, Bieliński DM, Anyszka R, Dul J, Parys G. Microstructure evolution of silicone rubber-based composites during ceramization at different conditions. Int $\mathrm{J}$ Adv Mater Manuf Charact. 2012;1:29-35.

8. Hanu LG, Simon GP, Cheng YB. Thermal stability and flammability of silicone polymer composites. Polym Degrad Stab. 2006;91:1373-9.

9. Hanu LG, Simon GP, Mansouri J, Burford RP, Cheng YB. Development of polymer-ceramic composites for improved fire resistance. J Mater Process Technol. 2004;153-154:401-7.

10. Ceramifying Process, Figure 2, In: Products. http://www.cer ampolymerik.com/products.htm. Accessed 1 Oct 2015.
11. Xiong Y, Shen Q, Chen F, Luo G, Yu K, Zhang L. High strength retention and dimensional stability of silicone/alumina composite panel under fire. Fire Mater. 2012;36:254-63.

12. Hanu LG, Simon GP, Cheng YB. Preferential orientation of muscovite in ceramifiable silicone composites. Mater Sci Eng, A. 2005;398:180-7.

13. Delebecq E, Hamdani-Devarennes S, Raeke J, Lopez Cuesta J-M, Ganachaud F. High residue contents indebted by platinum and silica synergistic action during the pyrolysis of silicone formulations. ACS Appl Mater Interfaces. 2011;3:869-80.

14. Anyszka R, Bieliński DM, Pędzich Z, Szumera M. Influence of surface-modified montmorillonites on properties of silicone rubber-based ceramizable composites. J Therm Anal Calorim. 2015;119:111-21.

15. Marosi G, Márton A, Anna P, Bertalan G, Marosföi B, Szép A. Ceramic precursor in flame retardant systems. Polym Degrad Stab. 2002;77:259-65.

16. Anyszka R, Bieliński DM, Pędzich Z, Zarzecka-Napierała M, Ziąbka M, Kowalczyk M. Effect of mineral fillers on properties of silicone rubber-based ceramizable composites. Part 1. Kinetics of vulcanization and mechanical properties of composites. Przem Chem. 2014;93:1291-5.

17. Hamdani S, Longuet C, Perrin D, Lopez-cuesta JM, Ganachaud F. Flame retardancy of silicone-based materials. Polym Degrad Stab. 2009;94:465-95.

18. Huang H, Tian M, Liu L, Liang W, Zhang L. Effect of particle size on flame retardancy of $\mathrm{Mg}(\mathrm{OH})_{2}$-filled ethylene vinyl acetate copolymer composites. J Appl Polym Sci. 2006;100:4461-9.

19. Bocz K, Krain T, Marosi G. Effect of particle size of additives on the flammability and mechanical properties of intumescent flame retarded polypropylene compounds. Int J Polym Sci. 2015. doi: $10.1155 / 2015 / 493710$.

20. Airbus' focus on "thermoplastic" composite materials brings environmental and production improvements. In: News \& Events. 2015. http://www.airbus.com/newsevents/news-events-single/detail/ airbus-focus-on-thermoplastic-composite-materials-brings-environ mental-and-production-impro/. Accessed 1 Oct 2015.

21. Artemenko SE. Polymer composite materials made from carbon, basalt and glass fibers. Fibre Chem. 2003;35:226-9.

22. Noistering JF. Carbon fibre composites as stay cables for bridges. Appl Compos Mater. 2000;7:139-50.

23. Mayer P, Kaczmar JW. Właściwości i zastosowania włókien węglowych i szklanych. Tworzywa Sztuczne i Chemia. 2008;6: $52-6$. 